San Jose State University

SJSU ScholarWorks

Master's Theses

Master's Theses and Graduate Research

Fall 2015

\title{
Diversity and Community Structure of Marine Invertebrate Fossil Assemblages from the Neogene of the Dominican Republic
}

Nina Abdollahian

San Jose State University

Follow this and additional works at: https://scholarworks.sjsu.edu/etd_theses

\section{Recommended Citation}

Abdollahian, Nina, "Diversity and Community Structure of Marine Invertebrate Fossil Assemblages from the Neogene of the Dominican Republic" (2015). Master's Theses. 4616.

DOI: https://doi.org/10.31979/etd.h4gw-2jk7

https://scholarworks.sjsu.edu/etd_theses/4616

This Thesis is brought to you for free and open access by the Master's Theses and Graduate Research at SJSU ScholarWorks. It has been accepted for inclusion in Master's Theses by an authorized administrator of SJSU ScholarWorks. For more information, please contact scholarworks@sjsu.edu. 


\title{
DIVERSITY AND COMMUNITY STRUCTURE OF MARINE INVERTEBRATE
} FOSSIL ASSEMBLAGES FROM THE NEOGENE OF THE DOMINICAN REPUBLIC

\author{
A Thesis \\ Presented to \\ The Faculty of the Department of Geology \\ San José State University \\ In Partial Fulfillment \\ of the Requirements for the Degree \\ Master of Science
}

By

Nina Abdollahian

December 2015 
(C) 2015

Nina Abdollahian

ALL RIGHTS RESERVED 
The Designated Thesis Committee Approves the Thesis Titled

DIVERSITY AND COMMUNITY STRUCTURE OF MARINE INVERTEBRATE FOSSIL ASSEMBLAGES FROM THE NEOGENE OF THE DOMINICAN REPUBLIC

by

Nina Abdollahian

APPROVED FOR THE DEPARTMENT OF GEOLOGY

SAN JOSÉ STATE UNIVERISTY

December 2015

Dr. Jonathan Hendricks

Dr. Shannon Bros-Seemann

Dr. Paula Messina
Department of Geology

Department of Biological Sciences

Department of Geology 


\begin{abstract}
DIVERSITY AND COMMUNITY STRUCTURE OF MARINE INVERTEBRATE FOSSIL ASSEMBLAGES FROM THE NEOGENE OF THE DOMINICAN REPUBLIC by Nina Abdollahian
\end{abstract}

River valleys in the Cibao Valley Basin, located in the northern Dominican Republic, expose three fossiliferous Neogene-aged strata (the Cercado, Gurabo, and Mao formations) that show evidence for shifting marine paleo-habitats. This study system is ideal for analyzing the relationships between environmental changes and faunal community stability through time. A new database was developed from the published literature to examine changing diversity patterns and to determine if the Cibao Valley communities exhibited stasis over a 3 My time span (6.5 Ma to $3.5 \mathrm{Ma}$ ) across shallowto very deep-water environments. This database includes spatio-temporal occurrence data for 179 species of gastropods, bivalves, and corals. Analyses of diversity patterns reveal a high diversity of species in shallow- to deep-water depths, and a low diversity of species in very deep-water depths, as well as a low similarity of species through time across the different paleoenvironmental settings. An R-mode hierarchical cluster analysis illustrates two major clusters that were based mostly on the different paleoenvironments in which these species lived, while a Q-mode cluster analysis shows two major clusters, one consisting mostly of mollusk and the other of corals. Finally, a detrended correspondence analysis indicates higher species richness in intermediate-water depths and lower species richness in very deep-water depths. In total, these results indicate faunal instability though changing habitats across time in this study system. 


\section{ACKNOWLEDGEMENTS}

I would like to start by thanking my thesis advisor Dr. Jonathan Hendricks for all

of his support, patience, and guidance during my graduate experience for it has helped me grow academically as well as a person. My thesis also could not have been completed without the help and support of the rest of my committee: Dr. Shannon Bros-Seemann and Dr. Paula Messina. Their guidance and comments through the editing process were eye opening and has helped me become a better writer. I would also like to thank Dr. Paula Mikkelsen for granting permission on behalf of the Paleontological Research Institution for allowing me to reproduce a figure for my thesis. Finally, I would like to express my gratitude to my friends and family, I truly wouldn't be who I am and where I am today without them constantly by my side. 


\section{Table of Contents}

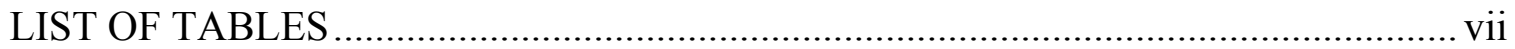

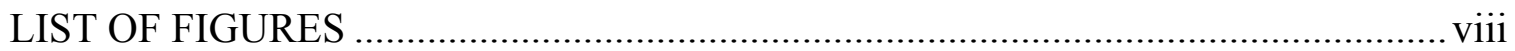

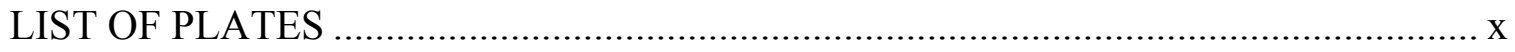

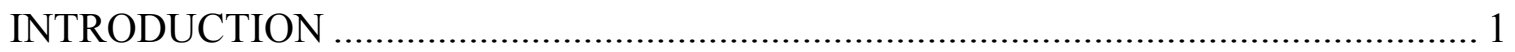

OVERVIEW OF FORMATIONS IN STUDY SYSTEM........................................ 2

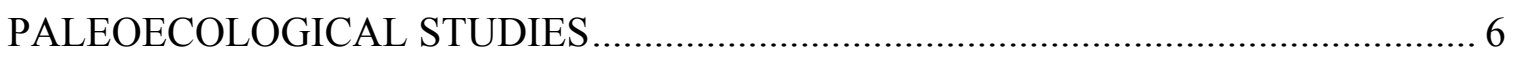

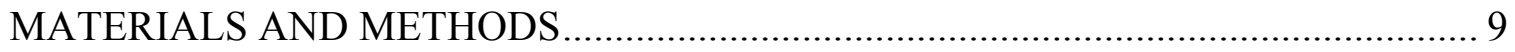

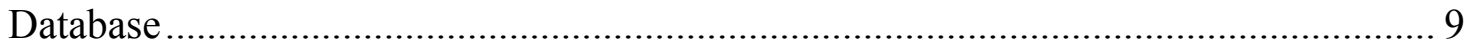

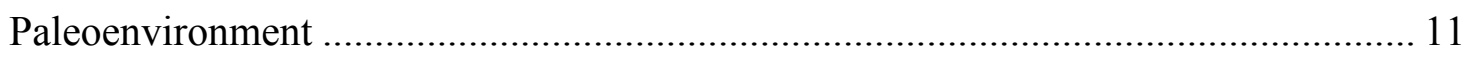

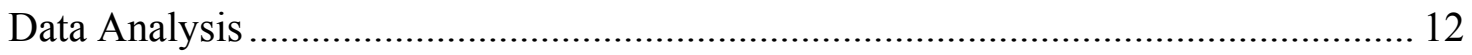

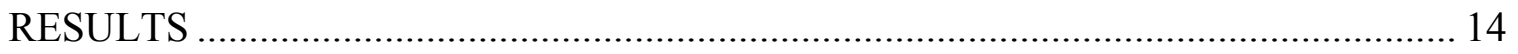

Overview of Dataset ................................................................................... 14

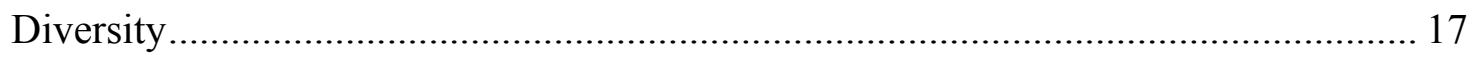

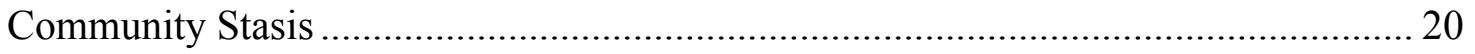

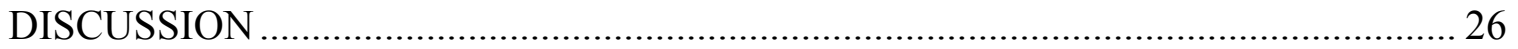

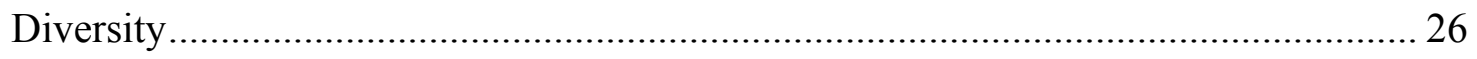

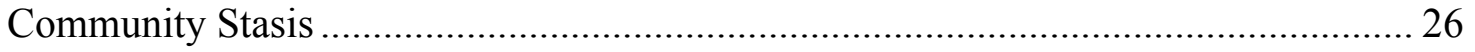

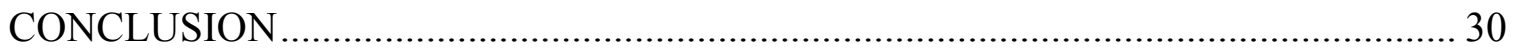

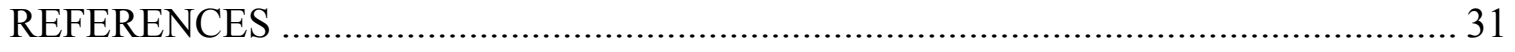




\section{LIST OF TABLES}

Table 1. The twenty-four taxonomic monographs published in the Bulletins of American Paleontology used to construct the core dataset analyzed in this study.................... 4

Table 2. Species counts and Jaccard similarity coefficient comparing values for each time bin from Río Gurabo and Río Cana, not including "range through" data................ 16 


\section{LIST OF FIGURES}

Figure 1. Cibao Valley Basin, located in the northern Dominican Republic, and the nine rivers where samples were collected (Text-Figure 3 from Saunders et al. 1986; reproduced with permission from the Paleontological Research Institution, Ithaca, New York).

Figure 2. Paleoenvironmental changes according to depositional and relative sea-level records in the Cibao Valley Basin (Modified from fig. 15, mcneill et al. 2012),....... 6

Figure 3. Heat map showing species persistence through the three formations. Each column represents a fossil locality and each row represents a species within each family

Figure 4. Summary of diversity patterns between 6.5 Ma to 3.5 Ma from Río Gurabo and Río Cana, including diversity levels with and without "range through" occurrences.

Figure 5. Changes in diversity within the three formations and across different paleoenvironmental settings represented by total number of species in each formation from both Río Gurabo and Río Cana, including range through data: Cercado Fm., 82 species; Gurabo Fm., 143 species; and Mao Fm., 56 species 17

Figure 6. Changes in diversity over time and across different paleoenvironmental settings represented by the total number of species in each time bin from both Río Gurabo and Río Cana, including range through data: TB1, 90 species; TB2, 101 species; TB3, 110 species; TB4, 102 species; TB5, 38 species; and TB6, 54 species........... 18

Figure 7. Summary of diversity changes through time including "range through" data. . 20

Figure 8. Comparison of Jaccard similarity coefficient between the Cercado, Gurabo, and Mao formations for the 16 families of bivalves, gastropods and corals.

Figure 9. Dendrogram of an r-mode hierarchical cluster analysis; sample groupings are based on the euclidian distance measurement. Cluster 1 represents a shallow- to deep-water environment and cluster 2 represents a deep-water environment. $\mathrm{RG}=$ Río Gurabo; RC= Río Cana. Numbers refer to time bins 1-6.

Figure 10. Dendrogram from a Q-mode hierarchical cluster analysis; groupings are based on the Euclidian distance measurement. Cluster 1 represents shallow- to deep-water species and Cluster 2 represents deep-water species. See Plate 1 for more detail.... 24 
Figure 11. Results of the detrended correspondence analysis (DCA). Blue dots represent RG1-RG6 and RC1-RC6 while the black dots represent species. The shallow-water cluster incorporates RG1 and RC1, while the intermediate cluster incorporates RC2, RG2, RG3, RC4, RG4, and RC5. The deep cluster encompasses RC6 and RG6.... 25 


\section{LIST OF PLATES}

Plate 1. Dendrogram from a Q-mode hierarchical cluster analysis; groupings are based on the Euclidian distance measurement. 


\section{INTRODUCTION}

The Cibao Valley Basin, located in the northern Dominican Republic, was an open shelf marine habitat millions of years ago and has been evolving for the past $10 \mathrm{My}$. As a result of tectonic uplift, the valley basin has exposed deposits of Neogene marine sediments that record shifting environments and include an abundance of invertebrate fossils, especially corals, mollusks, bryozoans, and various microfossils (McNeill et al., 2012, Saunders et al., 1986). Aspects of this fauna have been studied by various authors and, as a result of their work, 23 monographs have been published in the Bulletins of American Paleontology (Table 1). These monographs describe the fossils, including where they were found, geographically and stratigraphically, as well as the geology of the region. The collection localities include river cuts (Río Cana, Río Gurabo, Río Mao, Río Amina, Cañada Zalaya, Río Yaque del Norte, Arroyo Puñal, and Río Verde) and the City of Santiago, as well as several road cuts (Fig. 1).

The main purpose of this study is to use the spatio-temporal occurrence data associated with Dominican fossils collected from Neogene strata exposed by two rivers, Río Gurabo and Río Cana, to investigate the diversity and community stability of bivalve, gastropod, and coral species across different environmental settings over time.

Community stability in this study system could indicate that species are able to gradually adapt to the changing ecosystem over a 3 My time span, while instability in the study area would indicate that species within these communities could not adapt to environmental shifts over time. 


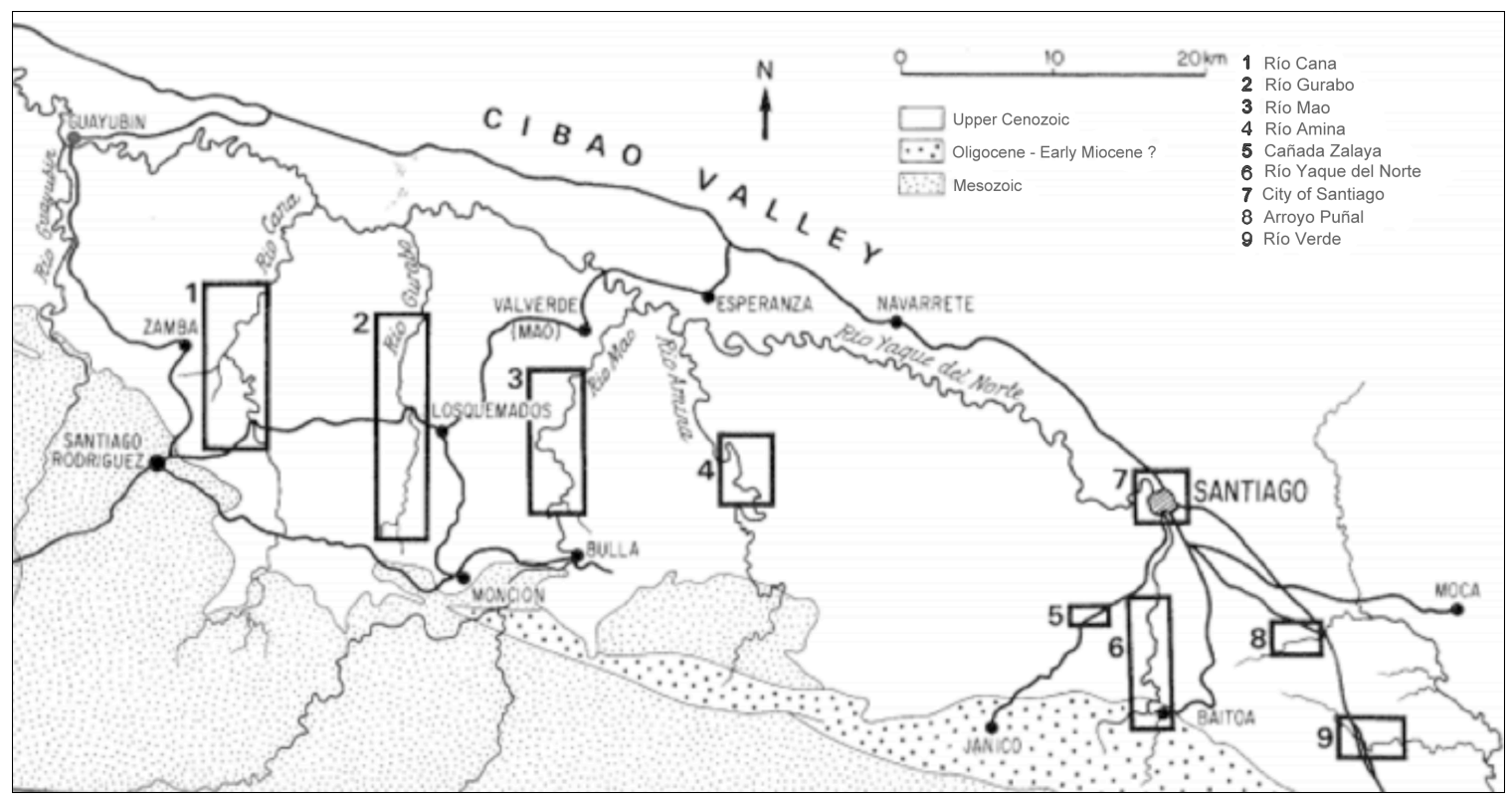

Figure 1. Cibao Valley Basin, located in the northern Dominican Republic, and the nine rivers where samples were collected (Modified from Text-Figure 3 from Saunders et al. 1986; reproduced with permission from the Paleontological Research Institution, Ithaca, New York).

\section{OVERVIEW OF FORMATIONS IN STUDY SYSTEM}

Three Neogene formations are exposed along nine rivers and road cuts in the Cibao Valley Basin: the late Miocene Cercado Formation, the early Pliocene Gurabo Formation, and the middle Pliocene Mao Formation. Each formation provides evidence of Neogene sea level fluctuations that occurred in the Cibao Valley Basin. The following overview is summarized from the recent review in McNeill et al. (2012).

The Cercado Fm. shows evidence for the first flooding in the Cibao Valley Basin around the Late Messinian (6.6-6.0 Ma), as evidenced by inner shelf sand deposits. As a result of the flooding and with an addition of ideal conditions (including high temperature and salinity, as well as low nutrient supply), coral reefs flourished in the Cibao Valley 
Basin during the deposition of this unit. The Cercado Fm. also shows evidence for a period of major sea level decline during the end-Messinian, as evidenced by coral reef deposits buried by siliciclastic material.

The early Pliocene Gurabo Fm. shows evidence of sea level oscillations between 5.6-4.0 Ma. The Gurabo Fm. records a transgressive period that led to an increase in sea level at about 5.3 Ma. Around 5.1 Ma, sea level fell and disturbed the normal marine conditions. Finally, during the late-early Pliocene, the occurrence of the foraminiferan Globorotalia margaritae showed evidence of warming and an increase in sea level in this study system.

The mid-Pliocene Mao Fm. shows evidence for a cycle of sea level rise and seaward progradation followed by a disconformity, which marks a period of sea level lowstand. These cycles are signified by the "mixed silt, sand, and coarse siliciclastic material ... that transition ... to interbedded coral and silt beds" (McNeill et al., 2012, p. 56), while the sea level drop is marked by coarse sand, gravel deposits, and a thick layer of marine deposits that include fossils. The sea level drop may have been a result of increased northern and southern hemisphere glacial activity, along with uplift of the Cordillera Central and Cibao Basin (McNeill et al., 2008). Finally, during the late Pliocene, the accumulation of marine deposits declined in the Cibao Valley Basin. This decline was due to the shallowing of the basin coupled with regional uplift, which restricted the Cibao Valley Basin, and also led to a sea level lowstand in the area (Fig. 2) (McNeill et al., 2008). 
Table 1. The twenty-four taxonomic monographs published in the Bulletins of American Paleontology used to construct the core dataset analyzed in this study.

\begin{tabular}{|c|c|c|}
\hline Series Number & Author (Year) & Taxon \\
\hline 1 & $\begin{array}{l}\text { Saunders, J., Jung P. and } \\
\text { Biju-Duval B. (1986) }\end{array}$ & $\begin{array}{l}\text { Field survey, lithology, } \\
\text { environment, and age }\end{array}$ \\
\hline 2 & Jung, P. (1986) & $\begin{array}{l}\text { Genus Strombina } \\
\text { (gastropod) }\end{array}$ \\
\hline 3 & Foster, A.B. (1986) & Family Poritidae (coral) \\
\hline 4 & Foster, A.B. (1987) & $\begin{array}{l}\text { Genus Stephanocoenia } \\
\text { (coral) }\end{array}$ \\
\hline 5 & $\begin{array}{l}\text { Cairns, S.D. and Wells } \\
\text { J.W. (1987) }\end{array}$ & $\begin{array}{l}\text { Suborders Caryophylliina } \\
\text { and Dendrophylliina (coral) }\end{array}$ \\
\hline 6 & Logan, A. (1987) & $\begin{array}{l}\text { Phylum Brachipoda } \\
\text { (brachiopod) }\end{array}$ \\
\hline 7 & $\begin{array}{l}\text { Van den Bold, W.A. } \\
\text { (1988) }\end{array}$ & $\begin{array}{l}\text { Subclass Ostracoda } \\
\text { (Crustacea) }\end{array}$ \\
\hline 8 & Vokes, E.H. (1989a) & $\begin{array}{l}\text { Family Muricidae } \\
\text { (gastropod) }\end{array}$ \\
\hline 9 & Vokes, H.E. (1989b) & Family Cardiidae (bivalve) \\
\hline 10 & $\begin{array}{l}\text { Jung, P. and Petit R.E. } \\
\text { (1990) }\end{array}$ & $\begin{array}{l}\text { Family Cancellaridae } \\
\text { (gastropod) }\end{array}$ \\
\hline 11 & Budd, A.F. (1991) & $\begin{array}{l}\text { Family Faviidae (Part I) } \\
\text { (coral) }\end{array}$ \\
\hline 12 & $\begin{array}{l}\text { Vokes, H.E. and Vokes } \\
\text { E.H. (1992) }\end{array}$ & Genus Spondylus (bivalve) \\
\hline 13 & Kier, P.M. (1992) & $\begin{array}{c}\text { Class Echinoidea (sea } \\
\text { urchin) }\end{array}$ \\
\hline 14 & $\begin{array}{l}\text { Nolf, D. and Stringer G.L. } \\
\text { (1992) }\end{array}$ & Otoliths of telestean fishes \\
\hline
\end{tabular}




\begin{tabular}{|c|c|c|}
\hline Series Number & Author (Year) & Taxon \\
\hline 15 & Jung, P. (1994) & $\begin{array}{c}\text { Genera Columbella, } \\
\text { Eurypyrene, Parametaria, } \\
\text { Conella, Nitidella, and } \\
\text { Metulella (gastropod) }\end{array}$ \\
\hline 16 & Anderson, L.C. (1996) & Family Corbulidae (bivalve) \\
\hline 17 & Jung, P. (1996) & $\begin{array}{c}\text { Families Cuspidariidae and } \\
\text { Verticordiidae (bivalve) }\end{array}$ \\
\hline 18 & Vokes E.H. (1998) & $\begin{array}{l}\text { Superfamily Volutacea } \\
\text { (gastropod) }\end{array}$ \\
\hline 19 & $\begin{array}{l}\text { Budd, A.F. and Johnson } \\
\text { K.G. (1999) }\end{array}$ & $\begin{array}{l}\text { Family Faviidae (Part II) } \\
\text { (coral) }\end{array}$ \\
\hline 20 & Stemann, T.A. (2000) & $\begin{array}{l}\text { The Family Agariciidae } \\
\text { (coral) }\end{array}$ \\
\hline 21 & Nehm, R.H. (2001a) & Genus Prunum (gastropod) \\
\hline 22 & $\begin{array}{l}\text { Costa, F.H.A., Nehm R.H. } \\
\text { and Hickman C.S. (2001) }\end{array}$ & Family Neritidae (gastropod) \\
\hline 23 & $\begin{array}{c}\text { Freiheit, J.R. and Geary } \\
\text { D.H. (2009) }\end{array}$ & $\begin{array}{l}\text { Genera Strombus and } \\
\text { Lobatus (gastropod) }\end{array}$ \\
\hline 24 & Waller, T.R. 2011 & $\begin{array}{l}\text { Propeamussiidae and } \\
\text { Pectinidae (bivalve) }\end{array}$ \\
\hline
\end{tabular}




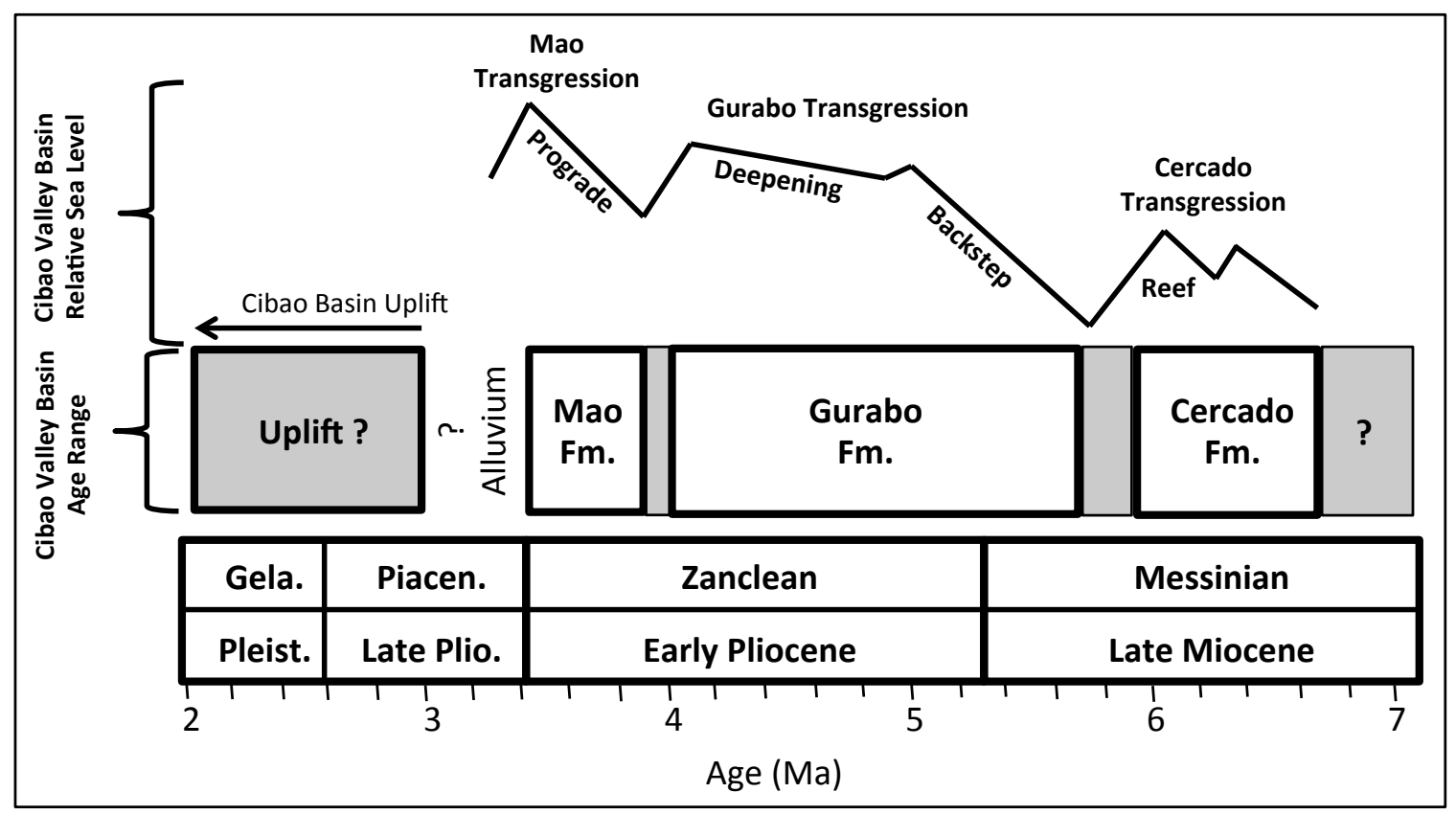

Figure 2. Paleoenvironmental changes according to depositional and relative sea-level records in the Cibao Valley Basin (Modified from fig. 15, McNeill et al. 2012).

\section{PALEOECOLOGICAL STUDIES}

The Cibao Valley Basin has been extensively studied due its rich abundance of Neogene fossils and evidence of shifting paleoenvironments, making this study area ideal for paleobiological research on the relationships between environmental change and faunal stability. Anderson (1994) examined how paleoenvironmental factors may have affected the distributional patterns of members of the bivalve clade Corbulidae in the Dominican Republic. One of her goals was to determine if the distributional patterns of the corbulid species are a result of speciation and extinction, or of migration. The author examined the Baitoa, Cercado, Gurabo, and Mao formations to determine the different paleoenvironments in the study area. She concluded that the Miocene deposits represent shallow marine conditions while the Pliocene deposits were deposited in deeper marine 
conditions. The corbulid species are eurytopic, tolerating a wide range of habitats, but favoring shallow marine waters. Corbulid species are more abundant and diverse in the Miocene than in the Pliocene deposits. Anderson's (1994) results indicate that the first appearances of the corbulids were in shallow marine deposits, and the last occurrences were correlated with deep-water sediments. The author concluded that the corbulid species distributions are correlated with paleoenvironmental oscillations, indicating that these species migrated in and out of the study area (Anderson, 1994).

Rivera et al. (2008) conducted a study on the variability of mollusk assemblages in the Dominican Republic. The authors focused on two stratigraphic units exposed at Río Gurabo: the Cercado Fm. (their G1) and the Gurabo Fm. (their G9). Their goal was to determine species richness patterns, and paleocommunity variation, and from there, understand the distribution and abundance patterns of more than 300 mollusk species. Rivera et al. (2008) found that the Gurabo Fm. has an upper and lower section, which have different species richness patterns. The bulk samples collected from the upper Gurabo Fm. had diversity ranges between $42-72$ species while the samples from the lower Gurabo Fm. had 20-35 species. Additionally, when comparing species richness values to the Cercado Fm., the Gurabo Fm. has an overall larger value. Rivera et al. (2008) performed a Non-metric Multidimensional Scaling (NMS) analysis that showed three main faunal groupings that were organized into lithostratigraphic zones: G1 (Cercado Fm.), G9 Zone A (upper Gurabo Fm.), and G9 Zone B (lower Gurabo Fm.). Finally, by using the three faunal zones, the authors were able to identify the mollusk distributional and abundance patterns in the Río Gurabo section. Rivera et al. (2008) 
found that only 21 species of mollusks (12 bivalves and 9 gastropods), from the 300 mollusk species analyzed, persisted from the older Cercado Fm. through the younger Gurabo Fm. Finally, within the different faunal zones (G1, G9 Zone A, and G9 Zone B) the abundance of these 21 species fluctuated but persisted through each lithostratigraphic unit (Rivera et al., 2008).

Klaus et al. (2008) investigated the community changes in coral assemblages during the Neogene in the Dominican Republic. These authors investigated whether coral communities were stable in species composition or if they changed in conjunction with environmental factors that varied over time. They studied about 4,000 coral specimens belonging to 104 species from the Cercado, Gurabo, and Mao formations. In order to study coral community variation through time, the authors focused on the coral species that were found in multiple formations, then analyzed whether each of those coral species was present or absent in each locality. In order to determine the degree of faunal stability, the authors used the Brett and Baird (1995) faunal stability minimum of $60 \%$. The authors found that of the 104 species, $61 \%$ of them persisted from the Cercado Fm. to the Mao Fm. They concluded from their initial test that these coral communities were faunally stable through time. Additionally, they recorded fossil coral presence/absence data for the 104 species in 21 lithostratigraphic units within the three formations, and used a cluster analysis to determine the variability within the communities. Bray-Curtis similarity indices indicated two distinct assemblage types: mixed-shaped corals and freeliving corals. Additionally, the cluster analysis demonstrated that the two coral assemblages were stable over the 3 My time span of the study interval. Finally, the 
authors used 27 20-m line transects from reef zones in Arroyo Bellaco, Cañada de Zamba, and Cana Gorge to determine the relative abundance and community stability of the species. This last test showed a decrease in similarity of branching corals and massive corals species through time. They concluded that the first two tests were broad analyses while their third test was a much more refined analysis that indicated a strong correlation between the community variation and environmental changes through time in the study system (Klaus et al., 2008).

\section{MATERIALS AND METHODS}

\section{Database}

A subset of the Dominican Republic fossil record has been published in 23 taxonomic monographs written by various authors and published in the Bulletins of American Paleontology (Table 1). A new species-level database of Neogene marine invertebrate species was compiled from these monographs. This core database included the following elements: 1) taxon name; 2) locality code; 3) stratigraphic formation; 4) general location; and 5) georeferenced latitude and longitude points. There were two types of localities recorded in this database: Tulane University collections (TU) and Naturhistorisches Museum Basel (NMB) collections. Google Earth (Google Inc., 2015) was used to georeference the latitude and longitude points of fossil localities that are found on river maps of Río Cana and Río Gurabo, published by Saunders et al. (1986).

This study focused only on records of bivalves, gastropods, and corals from Río Gurabo and Río Cana to identify potential community shifts in relation to stratigraphy. 
Thus, only 20 of the 23 taxonomic monographs were used. In addition to elements from the core database, the dataset utilized in this study also included the following information for each locality: its position in the stratigraphic section (in meters above the base), its paleoenvironmental interpretation based on Saunders et al. (1986) and Waller (2011) (see below), and an estimate of its absolute age. Two approaches were used to determine the stratigraphic position for each locality. The first approach used detailed stratigraphic sections for both Río Cana and Río Gurabo, published by Saunders et al. (1986), to determine an estimated $( \pm 10 \mathrm{~m})$ position for each locality in the section. The second approach matched TU and NMB locality numbers to stratigraphic information from Waller (2011) and Vokes (1989a), to obtain a more precise stratigraphic position. Additionally, absolute age information for each locality was estimated using figures 10 and 12 in McNeill et al. (2012), which are age-depth models for Río Cana and Río Gurabo. The age information was obtained by correlating where the locality lies in the stratigraphic section relative with the absolute age information given on the age-depth model (See supplementary data).

Community stability was examined by the presence and absence of species within these communities with respect to temporal changes in the habitats. Stratigraphic occurrences were divided into six time bins (TB1-TB6), each 500,000/years in length, to allow analysis of temporal trends across $3 \mathrm{My}$ of geological time (6.5 to $3.5 \mathrm{Ma})$. It is assumed that species persisted between their first and last occurrences; thus "range through" occurrences were applied to intervals in between, from which the taxon was not recovered. For example, if a sample was collected from TB1 and TB4, it must have 
persisted through TB2 and TB3, even if it was not collected from those time intervals.

The species in Río Gurabo and Río Cana were then organized into four presence/absence matrices indicating whether a species was present or absent in each time bin, formation, and paleoenvironment (see below), as well as the river cut from which they were collected.

\section{Paleoenvironment}

This study used rock lithology and fossil assemblages as proxies to estimate paleoenvironmental conditions of individual localities. Research by Nehm (2001a), indicated that gastropods belonging to the genus Prunum are a good proxy for determining water depth because modern representatives favor a shallow-water seagrass habitat (also see Waller, 2011). Vokes (1989a) found that the family Muricidae is also a good indicator for water depth because some species (or closely related species) from the Neogene of the Dominican Republic are extant and have known modern depth ranges. Using these gastropods, she indicated that the Cercado Fm. was deposited in water depths that were between 0-20 m, the lower Gurabo Fm. in water depths between 20-50 m, the middle Gurabo Fm. in water depths between 50-150 m, the upper Gurabo Fm. in water depths between 150-350 m, and the Mao Fm. in water depths below $350 \mathrm{~m}$. Waller's (2011) research on scallops in the Cibao Valley Basin was also especially helpful in reconstructing the paleo-habitats. Waller recognized five ecological settings (shallow shelf, middle to outer shelf, outer shelf edge, mud bottoms, and coral reef and carbonate sediments) and he characterized them based on the Propeamussiidae and Pectinidae 
scallop assemblages present. These assemblages represent fluctuating water depths, habitat changes on the sea floor, and evidence of coral reefs or marine grasses and algae (Waller, 2011). The Propeamussiidae and Pectinidae assemblages were used instead of the Muricidae species to determine the paleoecological settings within the Cercado, Gurabo, and Mao formations because the assemblages described by Waller (2011) provided more information on the paleo-habitats of individual localities.

\section{Data Analysis}

The relationship between species persistence through time and environmental change was examined with a gridded heat map based on presence/absence data (Wilkinson et al., 2008). Each row on the heat map represents a species, and each column represents a collection locality; the colors indicate the presence or absence of each species within each locality. Total species count (richness) in the analyzed groups was calculated in order to identify how the diversity of species changed through different time intervals (6.5 Ma to 3.5 Ma) and environments (shallow- to deep-water).

The Jaccard similarity coefficient $\left(\mathrm{S}_{\mathrm{J}}\right)$ (Real and Vargas, 1996) was used to measure the similarity in species composition across the three formations.

$\mathrm{S}_{\mathrm{j}}=\frac{C}{A+B-C} \quad \begin{aligned} & \text { where } A \text { is the number of species in the first formation only, } B \text { is number of } \\ & \text { species in the second formation only, and } C \text { is number of species in both } \\ & \text { formations }\end{aligned}$

The Jaccard similarity coefficient is a value between 0 and 1,0 representing least similarity in species composition and 1 representing absolute similarity. If, for example, the Jaccard similarity coefficient is 0.3 for species at boundary 1 (between two 
formations) then there is a low similarity of species between the formations. On the other hand, if the Jaccard similarity coefficient is 1 for species at boundary 2, then species have absolute similarity between the formations.

Hierarchical cluster analysis (Hammer and Harper, 2006) was used to evaluate the distribution of species through time and across different paleoenvironmental settings. Euclidian distance (Hammer and Harper, 2006) was used as a measure of species composition dissimilarity between pairs of samples. Clusters were created using the average linkage, paired group algorithm (Hammer and Harper, 2006). Two types of cluster analyses were conducted for this study: 1) an R-mode clustering, where the columns of the database represent taxa; and 2) Q-mode clustering, where the columns of the database represent samples. The R-mode cluster analysis represents how the sampling areas are related based on the co-occurrence of taxa, while the Q-mode cluster analysis represents how the taxa are related based on their co-occurrence in the sampling areas. The localities for the cluster analyses were broken up into the six different time bins for Río Gurabo (RG1-RG6) and Río Cana (RC1-RC6) as described above. Río Gurabo does not have any samples representing TB5.

Finally, relationship between paleoenvironmental factors and species composition were examined with a Q-mode Detrended Correspondence Analysis (DCA) (Hammer and Harper, 2006) to illustrate how the species cluster by water depth. The detrending method was used to better represent the distribution of species along a paleoenvironmental gradient. These last two methods, hierarchical cluster analysis and DCA, were conducted using PAST v3.0 (Hammer and Harper, 2006). 


\section{RESULTS}

\section{Overview of Dataset}

The database used for this study includes spatio-temporal occurrence information from 179 species of gastropods ( 88 species, 7 families), bivalves ( 53 species, 5 families), and corals (38 species, 4 families), which were collected from 309 different localities; these occurrences are summarized in Figure 3. The bivalve family Pectinidae (23 species), gastropod family Muricidae (42 species), and the coral family Faviidae (24 species) are the most species-rich families in this database. The highest total number of species ( $\mathrm{n}=93$ ) existed between 5.5 Ma and 5.0 Ma (TB3), while the lowest total number of species ( $\mathrm{n}=2$ ) existed between 4.5 and 4.0 Ma (TB5) (Table 2). The low species count in TB5 may be due to a sampling bias owing to a lack of preserved fossils of that age in the locality area. Thus, the majority of the species recorded from TB5 are "range through" occurrences (Fig. 4). 


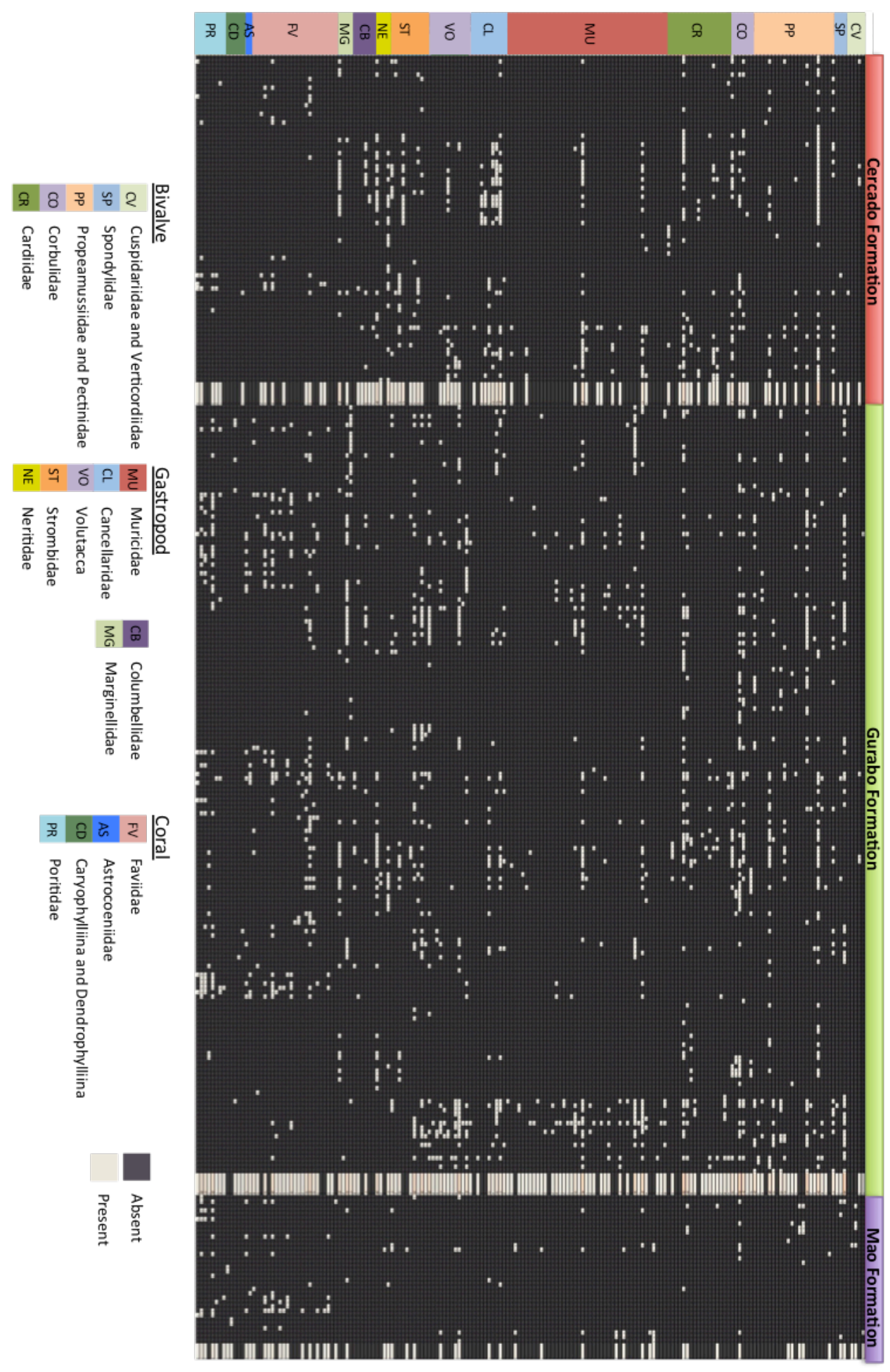

Figure 3. Heat map showing species persistence through the three formations. Each column represents a fossil locality and each row represents a species within each family. 
Table 2. Species counts and Jaccard similarity coefficient comparing values for each time bin from Río Gurabo and Río Cana, not including "range through" data.

\begin{tabular}{|c|c|c|c|c|}
\hline Time Bin & $\begin{array}{c}\text { Río Gurabo: } \\
\text { Species } \\
\text { Count }\end{array}$ & $\begin{array}{c}\text { Río Cana: } \\
\text { Species } \\
\text { Count }\end{array}$ & $\begin{array}{c}\text { Total } \\
\text { Number of } \\
\text { Species }\end{array}$ & $\begin{array}{c}\text { Jaccard } \\
\text { Similarity } \\
\text { Coefficient }\end{array}$ \\
\hline $\mathbf{6}$ & 51 & 37 & 54 & $\mathbf{0 . 6 3}$ \\
\hline $\mathbf{5}$ & 2 & 2 & 2 & $\mathbf{1 . 0 0}$ \\
\hline $\mathbf{4}$ & 91 & 67 & 91 & $\mathbf{0 . 7 4}$ \\
\hline $\mathbf{3}$ & 80 & 83 & 93 & $\mathbf{0 . 7 5}$ \\
\hline $\mathbf{2}$ & 82 & 77 & 89 & $\mathbf{0 . 7 9}$ \\
\hline $\mathbf{1}$ & 72 & 82 & 90 & $\mathbf{0 . 7 1}$ \\
\hline
\end{tabular}

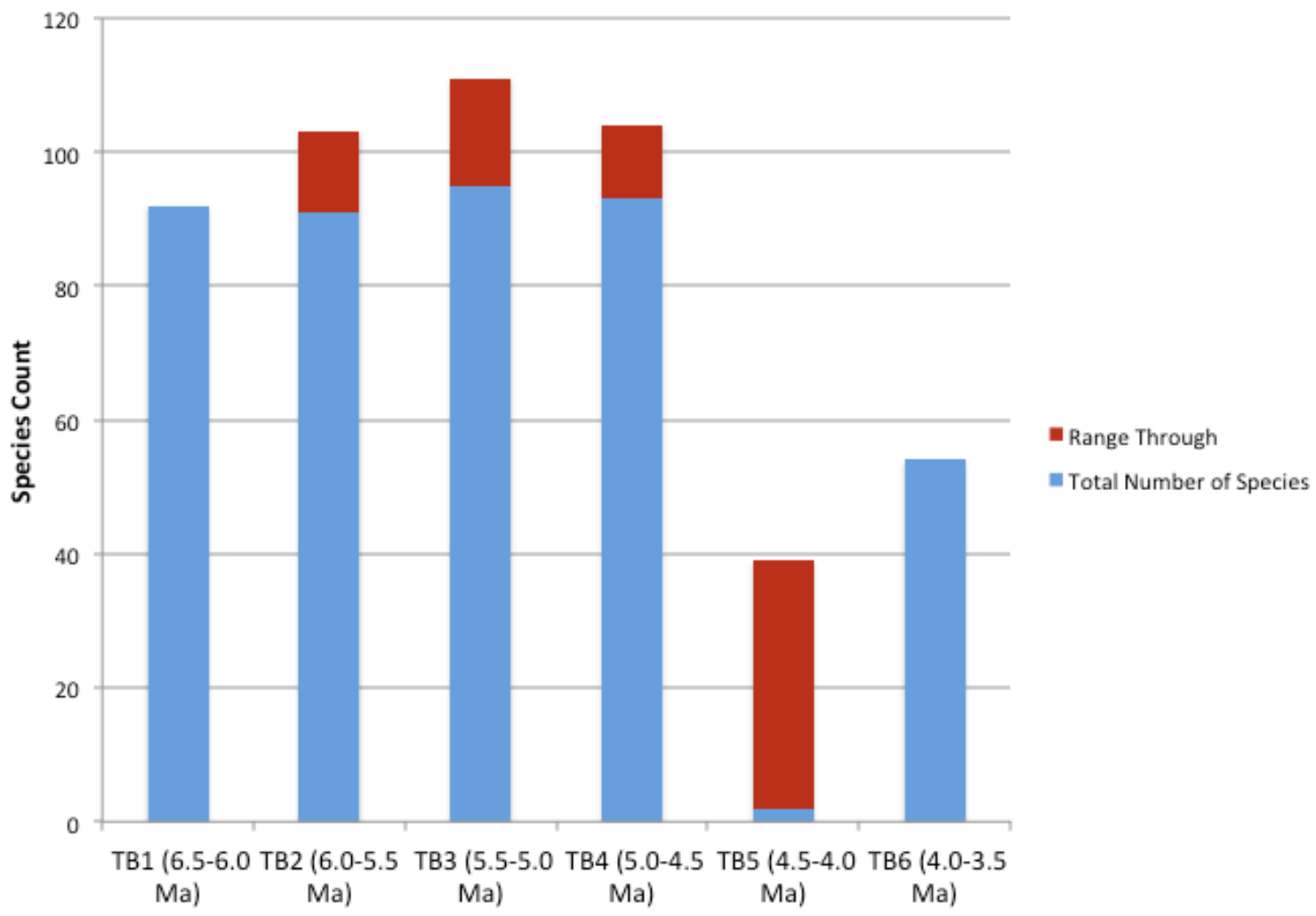

Figure 4. Summary of diversity patterns between 6.5 Ma to 3.5 Ma from Río Gurabo and Río Cana, including diversity levels with and without "range through" occurrences. 


\section{Diversity}

Species diversity was lowest in deep-water habitats and highest in the habitats representing intermediate-water depths. The Gurabo Fm., which represents intermediatewater depth, had the highest diversity of species $(n=143)$ while the Mao Fm., which represents very deep-water, had the lowest diversity of species $(n=56)($ Fig. 5). This pattern is also observed in the time bin data, with TB1 to TB4 showing greater diversity than TB5 to TB6 (Fig. 6).

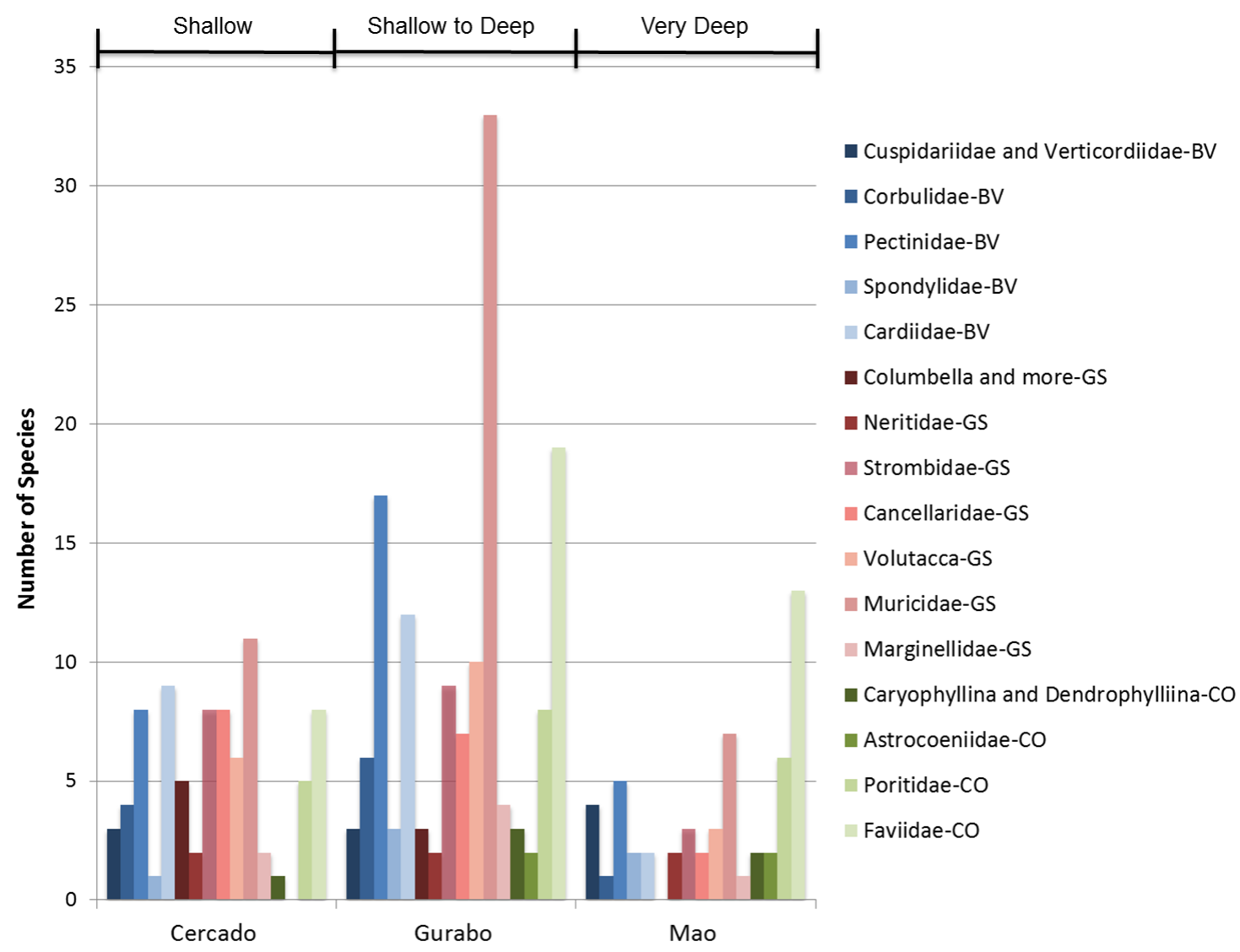

Figure 5. Changes in diversity within the three formations and across different paleoenvironmental settings represented by total number of species in each formation from both Río Gurabo and Río Cana, including range through data: Cercado Fm., 82 species; Gurabo Fm., 143 species; and Mao Fm., 56 species 


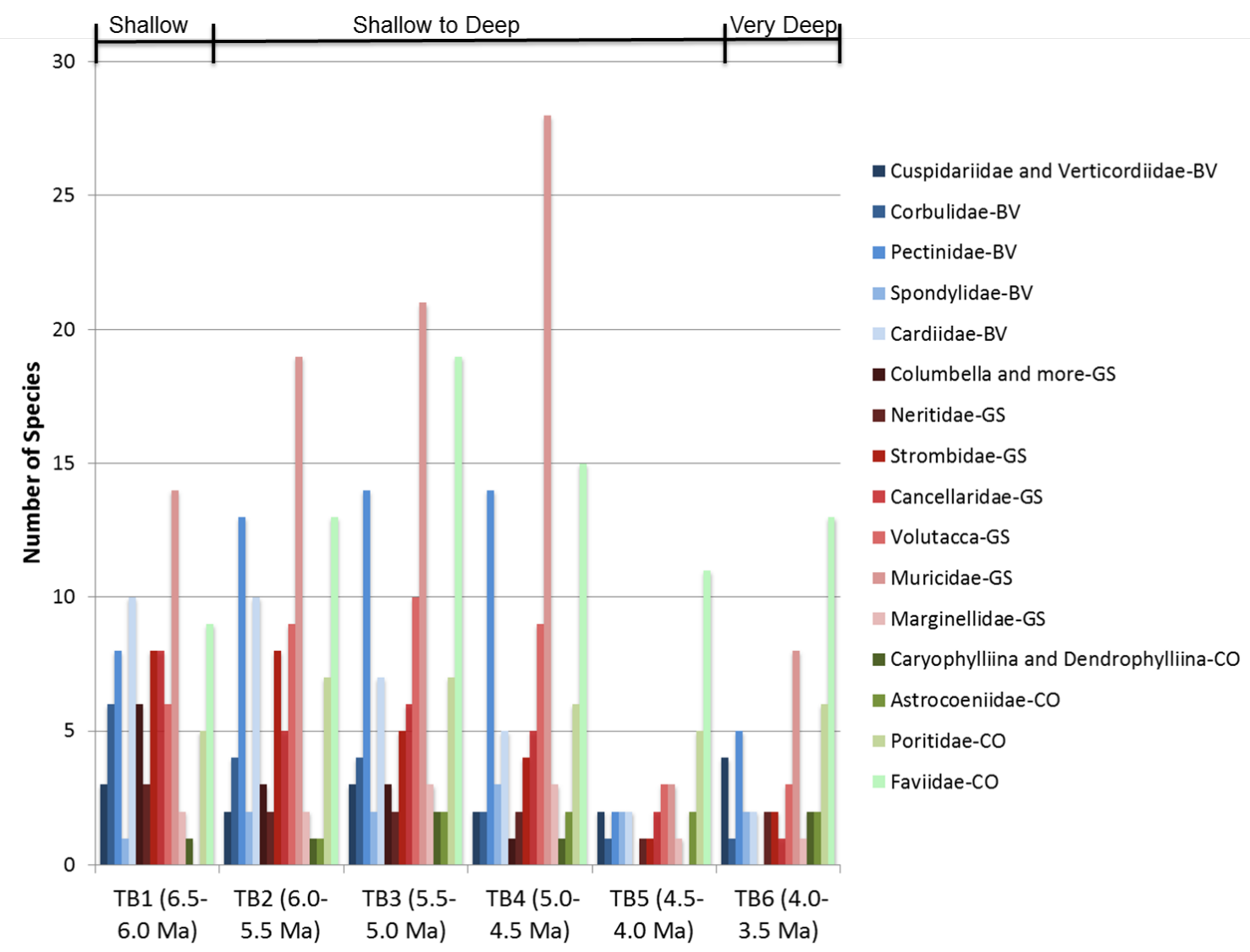

Figure 6. Changes in diversity over time and across different paleoenvironmental settings represented by the total number of species in each time bin from both Río Gurabo and Río Cana, including range through data: TB1, 90 species; TB2, 101 species; TB3, 110 species; TB4, 102 species; TB5, 38 species; and TB6, 54 species.

Figure 7 illustrates the changes in diversity of each family through time.

Between 6.5 Ma and 5.5 Ma (TB1 and TB2), during shallow-water conditions, the coral families Faviidae, Astrocoeniidae, and Poritidae increased in diversity, while Caryophylliina and Dendrophylliina species had no change in diversity. The mollusk family Muricidae and superfamily Volutacea increased in diversity, while the Strombidae and Marginellidae families had no change and the Cancellaridae, Neridae, and Columbellidae decreased in diversity. On the other hand, between 6.0 Ma and 5.0 Ma (TB2 and TB3), during shallow- to deep-water conditions, all of the coral families except 
Poritidae increased in diversity (the diversity of Poritidae species remained the same). Additionally, during this interval the mollusk family Muricidae and superfamily Volutacea increased in diversity, while the diversity of the Strombidae and Marginellidae families stayed the same, and the Cancellaridae, Neritidae and Columbellidae decreased in diversity (Fig. 7). From 5.5 Ma to $4.5 \mathrm{Ma}$ (TB3 to TB4), the mollusk families either decreased in diversity or stayed the same, with the exception of two families, Spondylidae and Muricidae, which increased in diversity. In addition, between 5.0 Ma to 4.0 Ma (TB4 to TB5) all families decreased in diversity with the exception of Astrocoeniidae, which stayed the same. Finally, between 4.5 Ma to 3.5 Ma (TB5 to TB6) there was either no change in diversity or an increase in diversity for all families with the exception of the family Cancellaridae, which decreased in diversity. The average temporal duration of the species in the five bivalve families (1.42 My) and seven gastropod families (1.43 My) are similar through time, while the species in the four coral families (1.72 My) have a slightly higher average duration. 


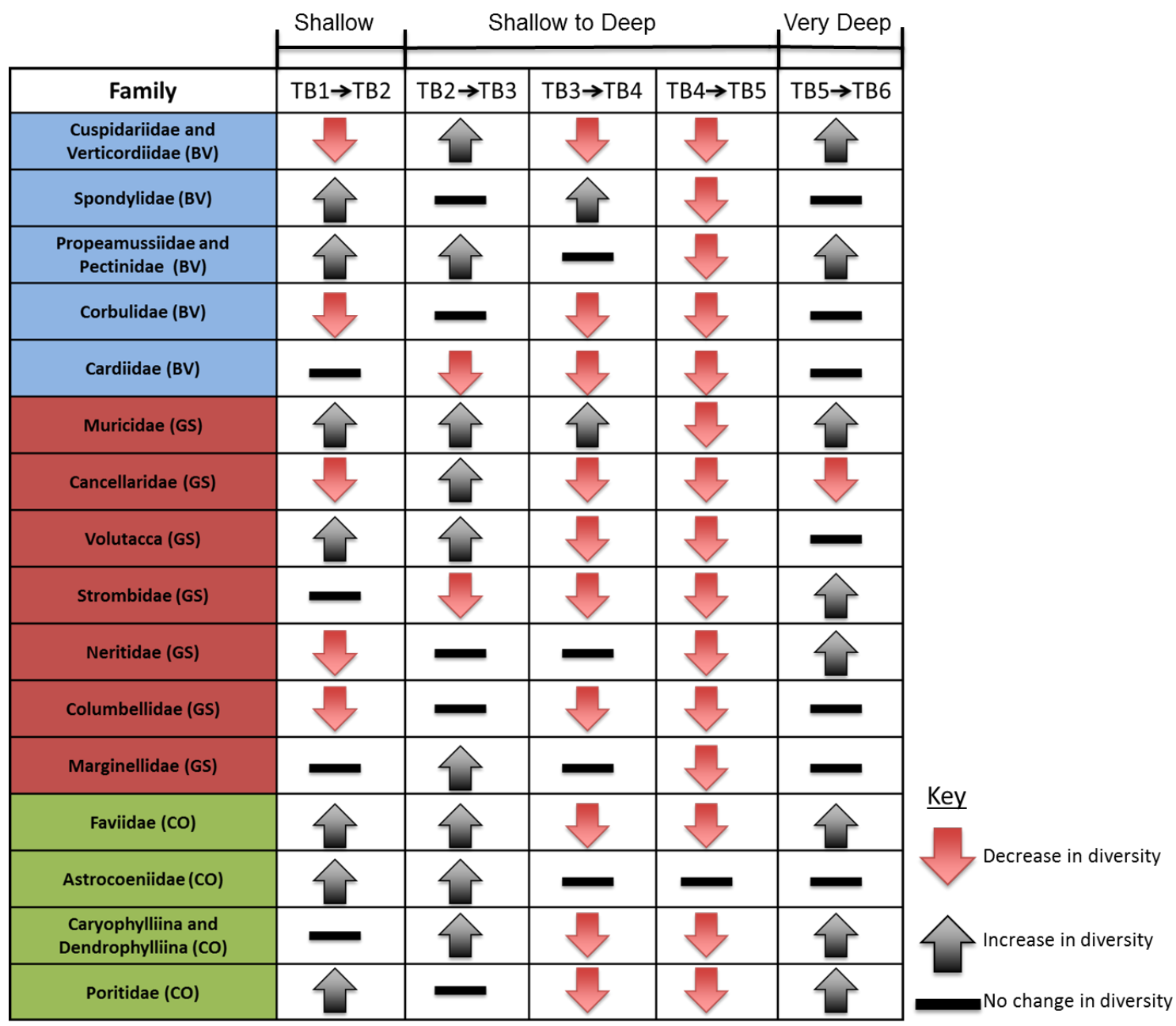

Figure 7. Summary of diversity changes through time including "range through" data.

\section{Community Stasis}

The Jaccard similarity coefficient results showed, on average, a low similarity of species among the three formations, which indicated community instability in the study area (Fig. 8). 


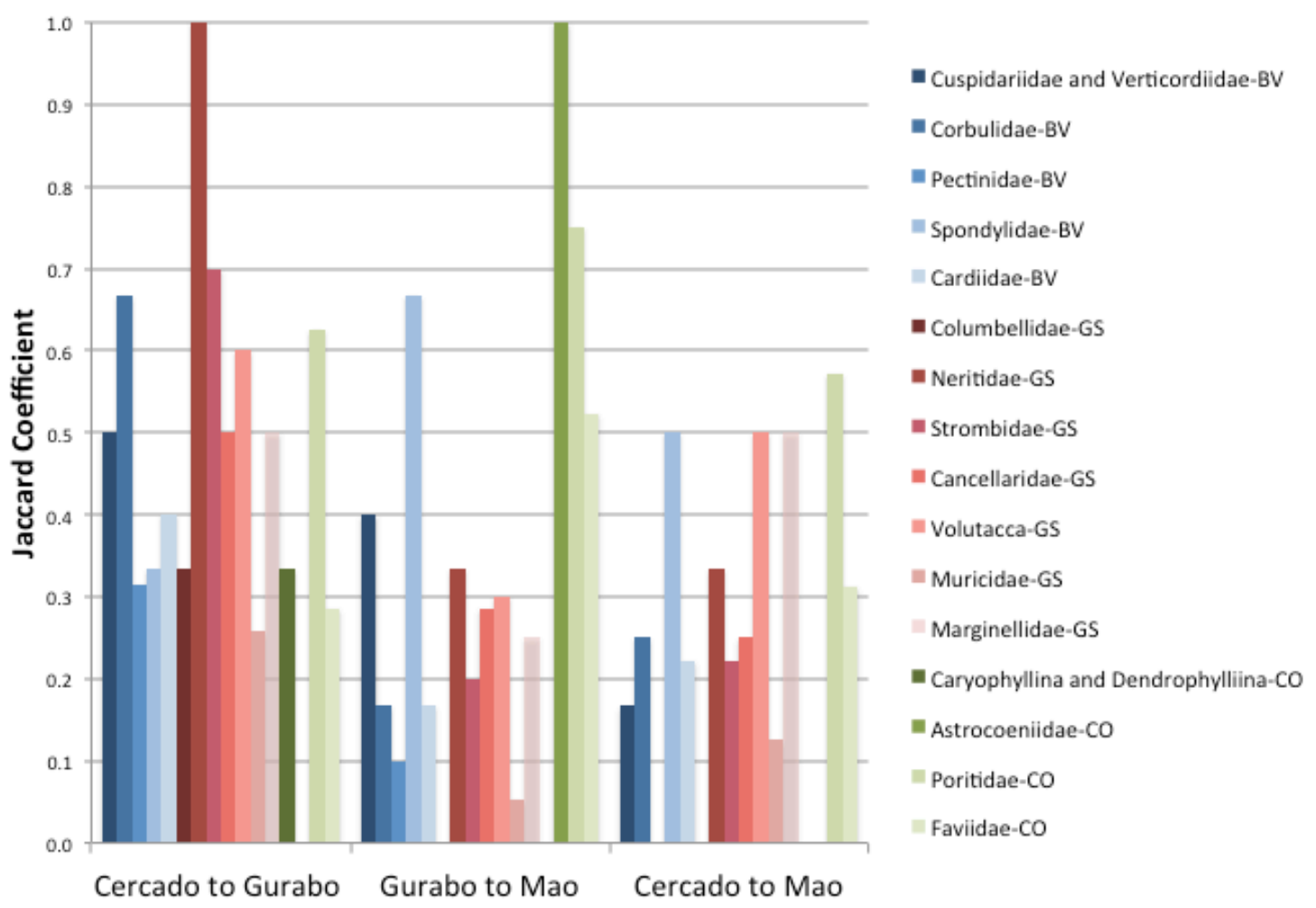

Figure 8. Comparison of Jaccard similarity coefficient between the Cercado, Gurabo, and Mao formations for the 16 families of bivalves, gastropods and corals.

The species from the five bivalve families (avg. $\mathrm{S}_{\mathrm{J}}=0.44$; range $=0.32-0.67$ ), seven gastropod families (avg. $\mathrm{S}_{\mathrm{J}}=0.56$; range $\left.=0.26-1.00\right)$, and four coral families (avg. $\mathrm{S}_{\mathrm{J}}=0.31$; range $=0-0.63$ ) have on average a low similarity from the Cercado Fm. to the Gurabo Fm. Likewise, the species from the bivalve (avg. $\mathrm{S}_{\mathrm{J}}=0.30$; range $=0.10-0.67$, gastropod $\left(\right.$ avg. $\mathrm{S}_{\mathrm{J}}=0.20$; range $\left.=0-0.33\right)$, and coral families $\left(\right.$ avg. $\mathrm{S}_{\mathrm{J}}=0.57$; range $=0$ 1.00) have on average a low similarity from the Gurabo Fm. to the Mao Fm. Finally, the average similarity of species from the bivalve $\left(\operatorname{avg} . \mathrm{S}_{\mathrm{J}}=0.23\right.$; range $\left.=0-0.50\right)$, gastropod $\left(\right.$ avg. $\mathrm{S}_{\mathrm{J}}=0.28 ;$ range $\left.=0-0.50\right)$, and coral $\left(\right.$ avg. $\mathrm{S}_{\mathrm{J}}=0.22 ;$ range $\left.=0-0.57\right)$ families between the Cercado Fm. and the Mao Fm. is low. Of the 179 species only 14\% persisted from the Cercado Fm. to the Mao Fm. 
Hierarchical cluster analysis showed that species richness was higher in shallowto deep-water environments and lower in very deep-water environments. The R-mode Cluster 1 represents a shallow- to deep-water environment (TB1 to TB4), while Cluster 2 represents a predominantly deep-water environment (TB4 to TB6), with the exception of one basally branching shallow-water grouping (RG1) (Fig. 9). The Q-mode analysis also generated two large clusters; Cluster 1 included almost all the mollusk species ( $\mathrm{n}=137)$, and a total of 23 coral species, while Cluster 2 included 14 coral species and 4 mollusk species (Fig. 10).

The DCA revealed that more species were found in intermediate-water depths rather than shallow- or deep-water depths through time. The DCA results were separated into three groups, which are highlighted as shallow, intermediate, and deep (Fig.11). These groups were divided by hand based on the time intervals, which represent the different habitats. According to this analysis, there were more species found in the intermediate-water depths and fewer found in the deep-water environments. Additionally, the deep-water habitat showed evidence for shallow-water species, which may be a result of transportation (see discussion below). 

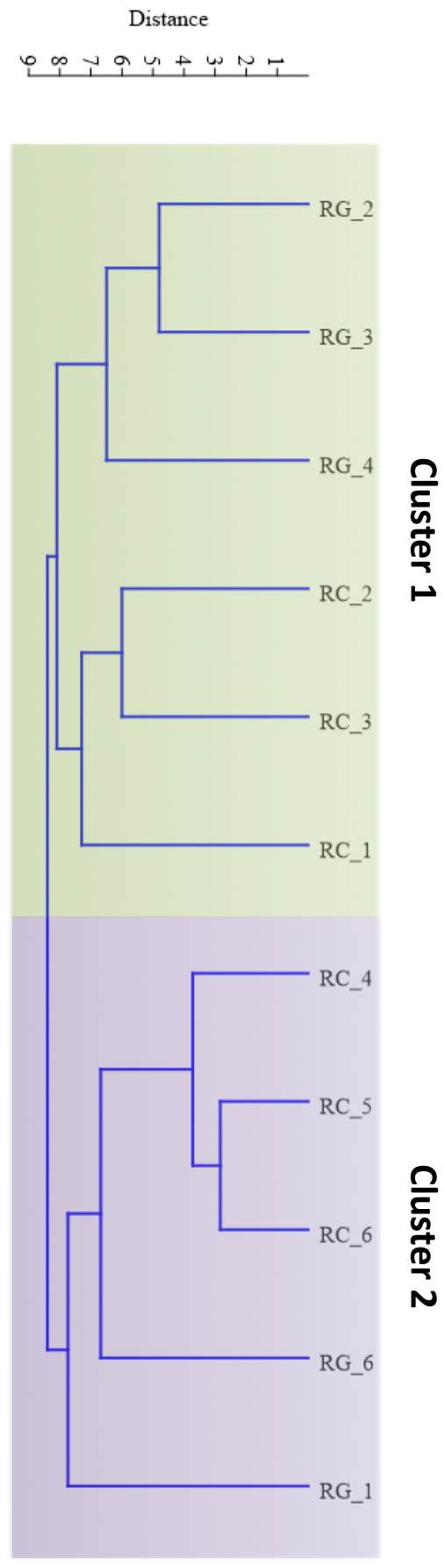

Figure 9. Dendrogram of an R-mode hierarchical cluster analysis; sample groupings are based on the Euclidian distance measurement. Cluster 1 represents a shallow- to deepwater environment and Cluster 2 represents a deep-water environment. $\mathrm{RG}=$ Río Gurabo; $\mathrm{RC}=$ Río Cana. Numbers refer to time bins 1-6. 


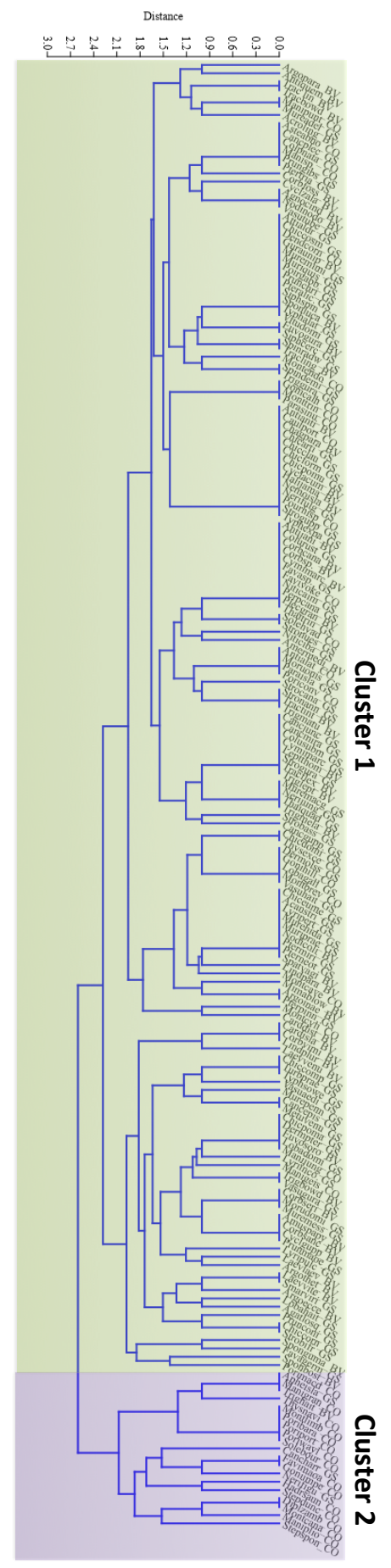

Figure 10. Dendrogram from a Q-mode hierarchical cluster analysis; groupings are based on the Euclidian distance measurement. Cluster 1 represents shallow- to deepwater species and Cluster 2 represents deep-water species. See Plate 1 for more detail. 


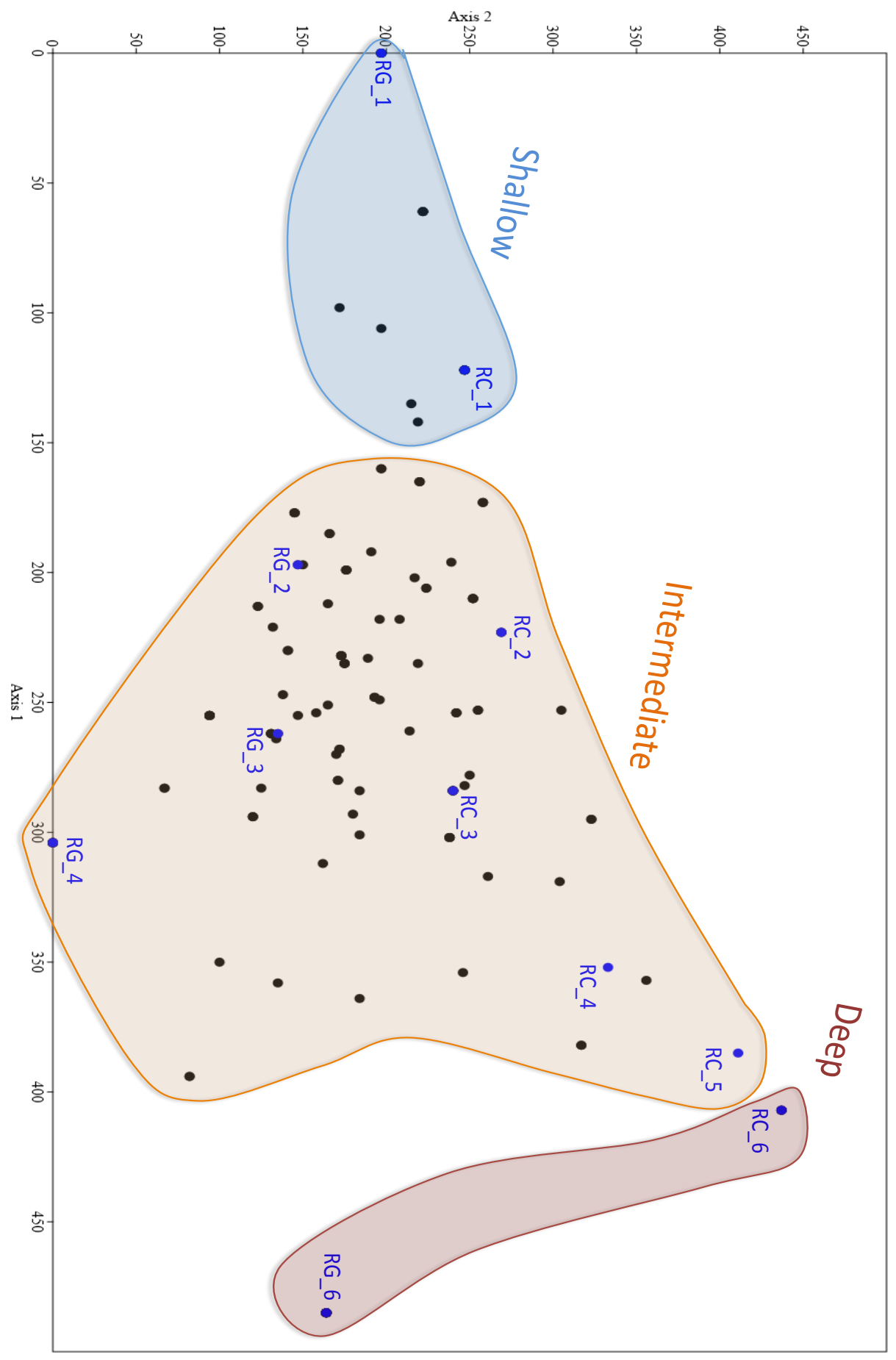

Figure 11. Results of the detrended correspondence analysis (DCA). Blue dots represent RG1-RG6 and RC1-RC6 while the black dots represent species. The shallow-water cluster incorporates RG1 and RC1, while the intermediate cluster incorporates RC2, RG2, RG3, RC4, RG4, and RC5. The deep cluster encompasses RC6 and RG6. 


\section{DISCUSSION}

\section{Diversity}

The paleontology and geology of the Cibao Valley Basin has been thoroughly studied, but a comprehensive analysis of diversity and paleoecological patterns within this region has yet to be undertaken, in part because systematic studies for many groups have not yet been completed. Furthermore, the database created for this study does not include species abundance, without which any analysis of diversity will be limited. However, this study does show a pattern of species-level diversity change over time and across different paleoenvironmental settings. There is a clear decline in species diversity from 5.0 Ma to 4.0 Ma in all families (Fig. 6). This decline may be a result of the sampling bias in the 4.5 Ma to 4.0 Ma time interval. The majority of this time interval consists of "range through" data, as only two species were collected within this span of time, and only $20 \%$ of the species persist from 5.0 Ma to $3.5 \mathrm{Ma}$ (Fig. 4). Additionally, between 4.0 Ma and 3.5 Ma, there was either no change in diversity or an increase in

diversity for all families, with the exception of the Cancellaridae. This could also be due to the sample bias during the 4.5 Ma to 4.0 Ma interval (TB5).

\section{Community Stasis}

The Neogene of the Cibao Valley Basin is an ideal system for exploring the relationship between habitat change and associated biotic responses over geological timescales. The results of this study show faunal instability in the presence of environmental changes over time. The Jaccard similarity coefficient showed that species 
similarities within families and between most of the study formations are significantly lower than 1, indicating faunal instability within this study system (Fig. 8).

The cluster analysis in Figure 9 shows a separation between two types of paleoenvironments in this study area; Cluster 1 (6.5 Ma - 5.0 Ma) represents a shallowwater environment and Cluster $2(5.0 \mathrm{Ma}-3.5 \mathrm{Ma})$ represents a deep-water environment. Cluster 2, however, represents a link between a shallow-water environment and a deepwater environment due to shallow-water species being present in a deeper water environment. According to Budd et al. (1999), Faviidae species have been found in slump deposits in deeper water deposits (i.e., were transported from shallower habitats). Additionally, Vokes (1989a) found evidence for gravity-flows in five localities (TU $1352,1366,1413$, NMB 15832, 15833) in this study area. Within these five localities, five shallow-water species (Chicoreus cornurectus, Corbula (Caryocorbula) sericea, Lyria (Lyria) pulchella, Morum (Oniscidia) domingense, and Murex messorius) were part of RG1. The presence of some shallow-water species in the deep-water environments suggests that these species were transported to deeper waters after death. The cluster analysis in Figure 10 represents two different clusters where mollusks tend to group together in Cluster 1 and corals tend to group together in Cluster 2. These taxa could be separating into these clusters based on the paleoenvironmental settings in which they existed.

The DCA in Figure 11 illustrated species distribution across time through the changing habitats. Axis 1 of the DCA represented the scores of the species while Axis 2 represented the scores of the time interval for each river (RC1-RC6 and RG1-RG6). The 
results show a larger number of species in intermediate-water environments, while there are fewer species recorded in the deeper water depths for both mollusk and coral species (Fig. 11). These results also indicate the presence of shallow-water species in deep-water environments, which is consistent with the results from the R-mode cluster analysis.

The results of the present study indicated that the mollusk and coral assemblages favor shallow- to intermediate-water depths rather than deeper water conditions, which is consistent with Anderson's (1994) research that showed a higher number of corbulid species during the Miocene (shallow- to intermediate-water depths) than in the Pliocene (deep-water depths). The results of this study also revealed that only $14 \%$ of the 179 species persisted from the late Miocene Cercado Fm. into the middle Pliocene Mao Fm., and from shallow- into deep-water environments. Similar results are found in research conducted by Rivera et al. (2008), which showed only 21 of more than 300 mollusk species $(<7 \%)$ persisted from the Cercado Fm. to the Gurabo Fm. in the Cibao Valley Basin. Furthermore, research by Klaus et al. (2008) on 104 coral species indicated faunal instability through the Cercado, Gurabo, and Mao formations. The results from this study are consistent with those of previous authors: a low percentage of species persist through time across the different paleoenvironmental settings, indicating faunal instability in the Cibao Valley Basin.

In a broader context, Cenozoic tropical American coral-reef faunas have been thoroughly studied by Budd (2000). Her results revealed three major extinction periods (Middle-Late Eocene, Late Oligocene-Early Miocene, and Plio-Pleistocene) of coralreef faunas that correlate with large-scale environmental changes. Additionally, the total 
number of species increased during intervals of high reef development (Middle-Late Eocene, Late Oligocene-Earliest Miocene, and Late Miocene-Late Pliocene). Budd (2000) also noted that the species composition from the Late Miocene to the Early Pliocene ( 8 to $4 \mathrm{Ma}$ ) more-or-less remained the same, and new species were added to communities during the Plio-Pleistocene. The results of Budd's (2000) analysis on Caribbean coral-reef faunas, which indicated no major decline in species composition through time across different paleoenvironmental settings, are at odds with the results of the present study because there was evidence for a decline in species composition.

A notable example of faunal stability comes from an analysis of invertebrate marine species collected from the Devonian Hamilton Group in the Appalachian Basin of New York State (Brett et al. 2007). The Hamilton Group is an ideal location for an analysis of faunal stability due to the diverse, well-preserved fauna, and the paleoenvironmental changes that occurred in the study system over a long period of time (Brett et al. 2007). The results of this study revealed that when an analysis of faunal stability was conducted on a narrow geographic scale, faunal instability was apparent in the study system. On the other hand, when the depositional environment of the basin was analyzed as a whole, the results indicated faunal stability within this system. In light of the work by Brett et al. (2007), further research should be conducted on faunal stability throughout the Cibao Valley Basin beyond the two river valleys considered here. Such future research could reveal whether faunal stability occurs throughout the basin or only in sections of the basin. Considering that abundance data were not available, additional research should also be conducted on the species diversity and paleoecology of this study 
system. Many of the invertebrate taxa from the Dominican Republic have remained unstudied, and thus the full scope of biodiversity patterns in this system will remain unknown without additional diversity data.

\section{CONCLUSION}

Using a newly developed database of marine invertebrate species from the Neogene of the Dominican Republic, species-level diversity trends and the community structure of 16 families of bivalves, gastropods, and corals were analyzed. The diversity patterns of the coral and mollusk species may appear to have fluctuated during this time period due to a sampling bias in TB5 (5.0-4.5 Ma). The R-mode cluster analysis indicated two clusters, one representing shallow- to deep- water environments and the other indicating very deep-water environments. The Q-mode cluster analysis also indicated two clusters, one including almost all mollusk species and the other including mostly coral species. The mollusks and corals were also found to have a low similarity of species from the Cercado Fm. to the Mao Fm. in the Cibao Valley Basin, with only $14 \%$ of species persisting across this $3 \mathrm{Myr}$ span. In addition, the species richness was higher in the intermediate-water depths and lower in the very deep-water depths. In all, the results of this study indicate an unstable community of species that fluctuated with the paleoenvironmental changes that occurred during the $3 \mathrm{My}$ time span in this study system. 


\section{REFERENCES}

Anderson, L.C., 1994, Paleoenvironmental Control of Species Distributions and Intraspecific Variability in Neogene Corbulidae (Bivalvia: Myacea) of the Dominican Republic: Journal of Paleontology, v. 68, p. 460-473.

Anderson, L.C., 1996, Neogene Paleontology in the northern Dominican Republic 16. The Family Corbulidae (Mollusca: Bivalvia): Bulletins of American Paleontology, v. 110, no. 351, p. 1-34.

Brett, C.E., and Baird, G.C.,1995, Coordinated stasis and evolutionary ecology of Silurian to Middle Devonian faunas in the Appalachian Basin, in Erwin, D.H., et al., eds., New Approaches to Speciation in the Fossil Record: New York, Columbia University Press, p. 284-315.

Brett, C.E., Bartholomew, A.J., and Baird, G.C., 2007, Biofacies Recurrence in the Middle Devonian of New York State: an Example with Implications for Evolutionary Paleoecology: Palaios, v. 22, p. 306-324.

Budd, A.F., 1991, Neogene Paleontology in the northern Dominican Republic 11. The Family Faviidae (Anthozoa: Scleractinia), Part I, The Genera Montastraea and Solenastrea: Bulletins of American Paleontology, v. 101, no. 338, p. 5-83.

Budd, A.F., Johnson, K.G., 1999, Neogene Paleontology in the Northern Dominican Republic 19. The family Faviidae (Anthozoa: Scleractinia) Part II. The genera Caulastraea, Favia, Diploria, Thysanus, Hadrophyllia, Manicina, and Colpophyllia: Bulletins of American Paleontology, no. 356, p. 6-37.

Budd, A.F., 2000, Diversity and extinction in the Cenozoic history of Caribbean reefs: Coral Reefs, v. 19, p. 25-35.

Cairns, S.D., and Wells J.W., 1987, Neogene Paleontology in the northern Dominican Republic 5. The Suborders Caryophylliina and Dendrophylliina (Anthozoa: Scleractinia): Bulletins of American Paleontology, v. 93, no. 328, p. 23-43.

Costa, F.H.A., Nehm, R.H., and Hickman, C.S., 2001, Neogene Paleontology in the northern Dominican Republic 22. The Family Neritidae (Mollusca: Gastropoda): Bulletins of American Paleontology, no. 359, p. 47-69.

Foster, A.B., 1986, Neogene Paleontology in the northern Dominican Republic 3. The family Poritidae (Anthozoa: Scleractinia): Bulletins of American Paleontology, v. 90 , no. 325 , p. $47-123$. 
Foster, A.B., 1987, Neogene Paleontology in the northern Dominican Republic 4. The Genus Stephanocoenia (Anthozoa: Scleractinia: Astrocoeniidae): Bulletins of American Paleontology, v. 93, no. 328, p. 5-22.

Freiheit, J.R., and Geary D.H., 2009, Neogene Paleontology of the northern Dominican Republic. 23. Strombid Gastropods (Genera Strombus and Lobatus; Mollusca: Gastropoda: Strombidae) of the Cibao Valley: Bulletins of American Paleontology, no. 376, p. 2-54.

Google Inc., 2015: Google Earth, Mountain View.

Hammer, Ø., and Harper, D.A., 2006, Paleontological Data Analysis: Malden, Blackwell Publishing, p.1-368.

Jung, P., 1986, Neogene Paleontology in the northern Dominican Republic 2. The genus Strombina (Gastropoda: Columbellidae): Bulletins of American Paleontology, v. 90, no. 324, p. 1-42.

Jung, P., 1994, Neogene Paleontology in the northern Dominican Republic 15. The Genera Columbella, Eurypyrene, Parametaria, Conella, Nitidella, and Metulella (Gastropoda: Columbellidae): Bulletins of American Paleontology, v. 106, no. 344, p. 6-45.

Jung, P., 1996, Neogene Paleontology in the northern Dominican Republic 17. The Families Cuspidariidae and Vertcordiidae (Mollusca: Bivalvia): Bulletins of American Paleontology, v. 110, no. 351, p. 1-45.

Jung, P., and Petit, R.E., 1990, Neogene Paleontology in the northern Dominican Republic 10. The Family Cancellaridae (Mollusca: Gastropoda): Bulletins of American Paleontology, v. 98, no. 334, p. 1-62.

Kier, P.M., 1992, Neogene Paleontology in the northern Dominican Republic 13. The Class Echinoidea (Echinodermata): Bulletins of American Paleontology, v. 102, no. 339 , p. 13-23.

Klaus, J.S., McNeill, D.F., Budd, A.F., and Johnson, K.G., 2008, Assessing community change in Miocene to Pliocene coral assemblages of the northern Dominican Republic, in Nehm, R.H., et al. eds., Evolutionary Stasis and Change in the Dominican Republic Neogene: Columbus, Springer Science + Business Media, p. 193-223.

Logan, A., 1987, Neogene Paleontology in the northern Dominican Republic 6. The Phylum Brachiopoda: Bulletins of American Paleontology, v. 93, no. 328, p. 4474. 
McNeill, F.D, Klaus, S.J., Evans, C.C., and Budd, F.A., 2008, An Overview of the Regional Geology and Stratigraphy of the Neogene deposits of the Cibao Valley, Dominican Republic, in Nehm, R.H. et al., eds., Evolutionary Stasis and Change in the Dominican Republic Neogene: Columbus, Springer Science + Business Media, p. 21-45.

McNeill, F.D., Klaus, S.J., Budd, F.A., Lutz, P.B., and Ishman E.S., 2012, Late Neogene chronology and sequence stratigraphy of mixed carbonate-siliciclastic deposits of the Cibao Basin, Dominican Republic: Geologic Society of America Bulletin, v. 124 , no. $1-2$, p. $35-58$.

Nehm, H.R., 2001a, Neogene Paleontology in the northern Dominican Republic 21. The Genus Prunum: Bulletins of American Paleontology, v. 359, p. 1-46.

Nolf, D., and Stringer G.L., 1992, Neogene paleontology in the northern Dominican Republic 14. Otoliths of teleostean fishes: Bulletins of American Paleontology, v. 102 , no. 340 , p. $46-81$.

Real, R., and Vargas, J.M., 1996, The Probabilistic Basis of Jaccard's Index of Similarity: Systematic Biology, v. 45, no. 3, p. 381-385.

Rivera, R., Lawson, J., Harvey, M., and Nehm, R.H., 2008, Mollusc assemblage variability in the Río Gurabo Section (Dominican Republic Neogene): Implications for species-level stasis, in Nehm, R.H. et al., eds., Evolutionary Stasis and Change in the Dominican Republic Neogene: Columbus, Springer Science + Business Media, p. 225-251.

Saunders, J.B., Jung, P., and Biju-Duval, B., 1986, Neogene paleontology in the northern Dominican republic 1. Field surveys, lithology, environment, and age: Bulletins of American Paleontology, v. 89, no. 323, p. 1-79.

Stemann, T.A., 2000, Neogene Paleontology in the northern Dominican Republic 20. The Family Agariciiade (Anthozoa: Scleractinia): Bulletins of American Paleontology, (in press).

Van den Bold, W.A., 1988, Neogene Paleontology in the northern Dominican Republic 7. The subclass Ostracoda (Arthropoda: Crustacea): Bulletins of American Paleontology, v. 94, p. 1-105.

Vokes, E.H., 1989a, Neogene Paleontology in the northern Dominican Republic 8. The Family Muricidae (Mollusca: Gastropoda): Bulletins of American Paleontology, v. 97 , no. 332, p. 1-94. 
Vokes, H.E., 1989b, Neogene Paleontology in the northern Dominican Republic 9. The Family Cardiidae (Mollusca: Bivalvia): Bulletins of American Paleontology, v. 97 , no. 332, p. $87-141$.

Vokes, H.E., and Vokes, E.H., 1992, Neogene Paleontology in the northern Dominican Republic 12. The genus Spondylus (Bivalvia: Spondylidae): Bulletins of American Paleontology, v. 102, no. 339, p. 1-13.

Vokes, E.H., 1998, Neogene Paleontology in the northern Dominican Republic 18. The superfamily Volutacea: Bulletins of American Paleontology, v. 113, no. 354, p. 154.

Waller, T.R., 2011, Neogene paleontology of northern Dominican Republic. 24.

Propeamussiidae and Pectinidae (Mollusca: Bivalvia: Pectinoidea) of the Cibao Valley: Bulletins of American Paleontology, no.381, p. 2-16.

Wilkinson, L., and Friendly, M., 2008, The History of the Cluster Heat Map: The American Statistician, v. 63, p. 179-184. 